\title{
Ecofriendly Dentistry: Save Today for a Better Tomorrow
}

\author{
Tomar Singh Prashant ${ }^{1}$, Gangishetti SaiRam ${ }^{2}$, Sindhe J Raghunand ${ }^{3}$ and Yadav Karthik D*4 \\ ${ }^{1}$ Master of Dental surgery, Department of oral and maxillofacial surgery, India \\ ${ }^{2}$ Senior Lecturer, Meghana Institute of Dental Sciences, India \\ ${ }^{3}$ Post graduate student, Bangalore Institute of Dental sciences, India \\ ${ }^{4}$ Master of Dental surgery - Department of oral medicine and radiology, India
}

Received: 制: September 21, 2018; Published: 制: October 15, 2018

*Corresponding author: Karthik D Yadav, $10^{\text {th }}$ Milestone, Bommanahalli, Hosur Road, Bangalore-560 102, India

\section{Short Communication}

The technological advancements reflect the progress and development that has been achieved by mankind over the years. This has been accomplished using the natural resources, that are abundantly available and are ecological, but after use the same resources which are discarded have been found to be harmful to the environment. Like a coin the two aspects of the same, wherein there is neither an account for resources utilized nor for the harmful substances that is discarded which is termed as "waste". Increasing environmental damage and its consequences over the decades has created awareness among the population. Further the need for accountability has of such harmful pollutants has gained importance and is now the topmost priority of mankind, which is reflected by the increasingly environmentally friendly practices that is being adopted nowadays. In the absence of voluntary environmentally friendly practices, it is being imposed by the regional regulatory bodies.

As quoted by Paul Hawken (1993) "The ultimate purpose of business is not, or should not be, simply to make money. Nor is it merely a system of making and selling things. The promise of business is to increase the general well-being of humankind through service, a creative invention and ethical philosophy." [1-3]. In the year 1970, the first Earth Day was celebrated [3]. Increased use of natural resources is mirrored by its reduced levels of availability. Environmental hazard not only includes air and water pollution but also includes increased areas of landfills with global warming effects which have makes saving our environment our motto [2]. It cannot be achieved by one person alone, but it also cannot be achieved without that one person also. It can be achieved by "reduce, recycle and reuse and rethink" The healthcare sector is no exception in waste generation. However, strict norms and self-consciousness along with programs to remind and enhance the education of the healthcare sector has greatly helped and kept the generation and disposal of biomedical waste in control. Dentistry is a part of the healthcare sector which serves to promote and enhance oral health by use of a variety of materials and equipment $[2,4]$.

Dentists have embraced practices to minimize waste generation, which impacts the environment. It includes but is not limited to treatment procedures and materials used during the procedure alone and takes in account other procedures like office administration, marketing, and construction, design of the operatory and the workspace, which is termed as green dentistry or eco-dentistry [2,5]. Eco-dentistry association defines green dentistry as "a high-tech approach that reduces the environmental impact of dental practices and encompasses a service model for dentistry that supports and maintains wellness" [2,6]. The principles encompass reduced waste generation, reduced power consumption, and pollution prevention, all focused on environmental protection [2]. In dentistry, research interest has been devoted to minimizing the environmental impact from mercury. Aside from mercury, to date there has been relatively little reported on dentistry's other environmental pollutants [7]. Waste disposal is a matter of concern for each practice, be it a hospital or a private setup $[7,8]$. The waste generated during dental practice includes sharps, chemical wastes, infectious wastes (blood-soaked cotton), gauze anatomical waste cultures, soiled waste, disposables mercury containing waste (mercury, amalgam scrap), lead containing waste (lead foil packets, lead aprons) and chemical waste which includes film developers and fixers and the disinfectants used [7-9]. The principles encompass - reduced waste generation, reduced power consumption, and pollution prevention

\section{Reduced Waste Generation can be Achieved by}

a) Use of recyclable disposable barriers

b) Sterilization of items

c) Avoid use of toxic disinfectant. 
d) Not to dispose chemical fixers into public sewer systems

e) Proper disposal of lead foils from $\mathrm{X}$ ray films

f) Replacement of conventional vacuum systems with High-tech, dry vacuum systems

g) Proper disposal of mercury-containing dental material

h) One of the easiest ways to start a going green initiative is to develop a waste reduction plan.

Whenever possible, waste reduction plans should include the four $[2,10]$ :
i. Recycle
ii. Reduce
iii. Reuse
iv. Rethink.

\section{Recycle}

Assemblage all sort of discarded amalgam and handing it over to a sanctioned recycler $[11,12]$.
a) Recycle developer \& fixer solutions.
b) Salvage lead foil from x-rays [11].
c) Use of reprocessed toner and inkjet cartridges.
d) Use of reprocessed supplies including paper towels, toilet tissue.
e) Refurbished office furniture.
f) Use of rechargeable batteries for cameras.
g) Re-tip or transform broken instruments.
h) Re-cycling of conventional instruments [13].

\section{Reduce}

a) Cut down water usage.

b) Hand sanitizer as a substitute of hand-washing $[14,15]$.

c) Turn off tap while soaping.

d) Educate patients with "Save 90 A Day" Campaign - to turn off the water while brushing [15].

e) Use dry high vacuum pressure pump, instead of the conventional wet one [11].

f) Always try to run full loads of sterilization equipment.

g) Use of low flow aerators in sinks.

h) Check for leaks throughout the office every 6 months [10].

i) Reducing the consumption of disposable items $[10,11,16]$.

j) Go "paperless"

k) Eradicate use of plastic bags [10].

\section{Reuse}

a) Replace cotton towels against disposable plastic/paper patient bibs.

b) Reusable stainless-steel high- and low-volume, surgical/ endodontic suction tips.

c) Biodegradable disposable cups as an alternative to regular paper cups.

d) Reuse paper $[10,11]$.

\section{Rethink}

A discussion/opinion with your fellow colleagues about some eco-friendly changes is always beneficial, as there may arise some new ideas.

\section{Energy Conservation}

a) Use concrete instead of bricks for construction.

b) Double walled glass for windows to lessen direct heat gain in addition to glare whereas maximizing sunlight entering your rooms.

c) Consumption of eco-friendly distemper like paint.

d) Installation of solar or tinted shades.

e) Make sure windows and doors are sealed tightly to prevent hot or cold air evasion inside or outside the building [10,11,17-20].

f) Turn off water heaters when not necessary.

g) Depending on the outside temperature, adjust the temperature while the office is closed to conserve electricity.

h) Up-to-date maintenance on the high-volume evacuation (HVE) system, autoclave and hand pieces.

i) Use of energy efficient machinery, having an ENERGY STAR® label and rating [10,11].

j) Regularly check items such as furnaces and air conditioning units.

k) Use LED monitors.

l) Turn off power, when unoccupied.

m) Reduce unnecessary light usage [19].

\section{Pollution Prevention}

Webster defines pollution as the contamination of air, soil and waters by the discharge of harmful substances [21]. Steps that can be taken in the dental office to prevent pollution:

a) Use of steam sterilization - prevents use of toxic chemicals [22,23].

b) Use of digital radiography $[11,22,24]$.

c) Avoid using cold sterilization solutions. 
d) Always use licensed handlers for offsite recycling of hazardous materials.

e) Train dental staff for proper disposal of amalgam.

f) Use of sodium hypochlorite as a disinfectant to disinfect vacuum lines should be avoided, as it enhances the release of mercury from amalgam [10,25].

\section{Conclusion}

The Four R's are the four pillars of saving the environment which comprises of recycle, reduce, reuse, and rethink. Dentists also can contribute in saving the environment, making it a better place to live, with higher impact made when greater number of dentists joins the green dentistry movement. This makes the world a cleaner and healthier place.

\section{References}

1. Hawken P (1993) The ecology of commerce: A declaration of sustainability. Revised edition. New York: Harper Collins Publisher.

2. Chopra A, Gupta N, Rao NC, Vashisth S (2014) Ecodentistry: The environment-friendly dentistry. Saudi J Health Sci 3(2): 61-65.

3. Newman E (2010) Going green making your dental practice environmentally friendly. AGD Impact 38: 1822.

4. Hiltz M (2007) The environmental impact of dentistry. J Can Dent Assoc 73(1): 5962.

5. Shetty V (2011) Green dentistry. JIAPHD 9(18): 891893.

6. Eco dentistry association. About green dentistry.

7. Khatoon KF, Akkifuddin S (2015) Awareness of Dental Auxillaries in Biomedical Waste Disposal: A Survey. J Adv Med Dent Scie Res 3(1): 4044.

8. $\mathrm{k}$ Last accessed on 13-1-2015.

9. Kumar VC, Manjunatha M, Vijetha B, Pradeep PR (2012) Biomedical Waste Management: A Review. J Oral Health Comm Dent 6(3): 141-144.

ISSN: 2574-1241

DOI: 10.26717/BJSTR.2018.10.001891

Karthik D Yadav. Biomed J Sci \& Tech Res

This work is licensed under Creative

Commons Attribution 4.0 License

Submission Link: https://biomedres.us/submit-manuscript.php
10. American dental association council on dental practice. go green: It's the right thing to do.

11. Adams E (2007) Ecofriendly dentistry: Not a matter of choice. J Can Dent Assoc 73(7): 581584.

12. Hanoon R (2011) What's with the green? Changes that help dentistry preserve the environment. RDH 31: 7486.

13. Hu friedy. Environdent.

14. Boyce JM, Pittet D (2002) Guideline for Hand Hygiene in Healthcare Settings. Recommendations of the Healthcare Infection Control Practices Advisory Committee and the HICPAC/SHEA/APIC/IDSA Hand Hygiene Task Force. Society for Healthcare Epidemiology of America/ Association for Professionals in Infection Control/Infectious Diseases Society of America. MMWR Recomm 51(16): 145.

15. Eco dentistry association. The global water crisis.

16. Donaldson K (2011) Is your office environmentally responsible? RDH 31(4): 4652.

17. Dutt P (2012) Green tea with gul. The Times of India (Times Life) 22: Sect. ETC: 2.

18. Satterfield Z (2009) Green building. Tech Brief 8: 14.

19. ADA. 150 ways to go green.

20. Henry K (2009) Go green dentistry. RDH 29: 5256.

21. Webster dictionary. Pollution.

22. Eco dentistry association green dentistry is high tech dentistry.

23. CDC (2008) Guideline for disinfection and sterilization in healthcare facilities.

24. Berkhout E, Sanderink G, Stelt (2003) Digital intraoral radiography in dentistry. Diagnostic efficacy and dose considerations. Oral Radiol 19(1): 113.

25. ADA (2007) Best management practices for amalgam waste.

$\begin{array}{ll}\text { BIOMEDICAL } & \text { Assets of Publishing with us } \\ \text { RESEARCHES } & \text { - Global archiving of articles } \\ \text { - Immediate, unrestricted online access }\end{array}$

